\title{
Research of University Library Subject Information Commons
}

\author{
Xinyu WANG ${ }^{1, \text { a }}$ \\ ${ }^{1}$ Library, Jilin Agricultural University, Changchun,130118, China \\ aemail:wangxinyu8303@126.com
}

Keywords: University library; Subject librarian; linformation sharing space; Subject information sharing space

\begin{abstract}
Subject-oriented service now has entered a deep developing period, which urgently need to find a break through point and establish an implemental model that is feasible, sustainable and suitable for the new information environment; Information commons (IC), which is a new kind of service model offers a valuable opportunity in service innovation. This is the future trend of modern library service innovation and development. On the basis of the similarities of IC and subject-oriented service, this paper conceptualized the mode of subject information commons (SIC) and discussed the construction of SIC with respect to space, resource and service.
\end{abstract}

\section{Introduction}

University library is the center of literature knowledge communication and communication. With the increasing popularity of the network information technology, the service function of the library has been expanded, and the service level has been significantly improved. The network has become the world's largest information service center, the library service put forward higher requirements, so that the management of the library is more challenging. University Library in the new historical period to continue to absorb the advanced management experience at home and abroad, the introduction of new service concept, give full play to the role of literature knowledge resources. To mobilize all human and financial resources of the library, to strengthen the knowledge management and scientific service.

\section{Information commons and subject service}

University Library Information Commons will integrate Internet technology, computer facilities, database resources and the condition of the premises. Under the guidance and help of the reference, the deep level of the subject service is integrated into the whole process of teaching and scientific research. Only when the subject service is embedded in the construction of the information sharing space, can we improve the quality of the subject service, and meet the diverse needs of information and teaching and research ${ }^{[1]}$.

The information commons model consists of 3 layers: the physical space layer, the virtual resource layer and the support service layer. The physical space is the basic condition of IC hardware layer, the bottom is located in IC structure model; virtual resource layer is the core part of IC, the middle layer is located in the IC model; support service layer at the top IC model, directly facing readers, show the function of IC value.

In order to meet the needs of readers, the library must innovate service model, to the new discipline service transformation. Subject service is based on the user's demand as the center, to carry out the knowledge management of the subject. Help users find solutions to solve the problem according to the needs of users. The idea of IC into the subject service, forming a space of information sharing, information sharing, it will double advantage of space and subject service integration, in particular, in the physical space, the integration of information resources and services of the subject. At the same time, it also has the unique characteristics of the virtual learning environment and communication community, users can enjoy the "one stop" of knowledge service in $\mathrm{IC}^{[2]}$. 


\section{The function of Library Information Commons Construction Based on the subject service}

Conducive to providing convenient services

The information commons based on the subject service is a reader centered, which can guide and assist students to explore the mystery of learning independently, so as to provide the readers with a full range of services.

conducive to the interaction between teachers and students to share

Readers have a comfortable and quiet learning environment, you can freely discuss and study here, but also to carry out a certain leisure and entertainment activities. Information sharing space creates a relaxed and free exchange platform, which is conducive to the further interaction between teachers and students to share ${ }^{[3]}$.

conducive to the implementation of the concept of people-oriented

Information commons can break through time and space constraints, the establishment of a virtual learning community, the formation of a wide area of knowledge sharing and exchange of space. Can not only provide a quiet environment for individual learning, but also to build a team of research space, in order to meet the needs of teachers and students to study the dual needs. Improve their enthusiasm, stimulate their creativity, so as to implement the "people-oriented, student oriented" teaching philosophy.

\section{The characteristics of information commons in the construction of high school}

Initiative and lead

Initiative and guidance is the foundation of the existence and development of IC, and it is also the requirement of library innovation subject service. Library should actively carry out cooperation with academic leaders. Let the subject librarian actively participate in the teaching and scientific research activities, the integration of IC in the subject services. IC should take the initiative to close to the students in the classroom and learning life. Establish thematic discussion group, subject community, interest hobby group, subject blog, etc., to attract professional teachers and students to the IC, and guide them to use the subject services to help their study and research.

Specialized

The subject service of information sharing space should provide information service for some key subjects and majors of the school, and to highlight the characteristics of knowledge, specialization, individuation and deepening. The subject service should be combined with the actual school, develop the overall development objectives and programs, improve the service mechanism of professional development, and understand the teaching and research of key disciplines, the latest research trends and cutting-edge information ${ }^{[4]}$. On this basis, give full play to the role of subject librarian, comprehensive collection of information, combined with the collection of information resources for deep processing, the establishment of subject information service system. The system can integrate the professional database, video courseware, discipline, academic reports and the teachers and students of the academic disciplines such as information materials, ensure the richness of information sharing space resources, provide deep subject service for readers, and promote the development of key disciplines of teaching and scientific research.

Sharing

The sharing of information resources is the meaning of the construction of IC in university library, and the subject service in IC should give full play to the superiority of information resources sharing. The library should grasp the school faculties and the construction of information resources and the departments of disciplines and specialties, subject librarians and faculty leadership through teaching and research staff communication, information resources to build a scientific researchers' information demand as the center of the sharing of cooperation, realize the library and faculty resource sharing space with rich professional literature for information sharing. 


\section{On the construction of library information sharing space based on the subject service}

Optimize the layout of library space

According to the service function, the library is divided into several areas, such as learning space, literature information and open information browsing area, consultation desk and leisure area. According to different service function, arrange the layout of the structure of the library. The consultation desk is set up in the front of the library. Because it is the channel for readers to seek help, through which readers can have a general understanding of the functions, layout and resources of the library, access to the basic information of the school and the library. Individual learning space, to be arranged in a distance, more independent and quiet area, so that readers can read the information, and independent thinking and writing. Team collaboration space should choose open loop layout. So that teachers and students can freely exchange and discuss, develop a fully open team cooperation, promote the realization of the goal of the team members ${ }^{[5]}$. Leisure area to create a focus on the environment, so that the teachers and students to appreciate the natural beauty of the natural beauty. Library in the separation of the region to achieve integration in order to fully integrate functional areas, the formation of a unified organic whole.

Integration of Library Information Resources

The integration of collections and virtual resources in Colleges and universities, improve the literature resources security system, establishing special database, the library should selectively integrate paper-based information collection, select application documents, to facilitate students to find resources effectively. The integration of electronic books, electronic newspapers, electronic journals and CD Database digital resources in the network, and with the help of discipline and network navigation, and remote access and other means to provide a one-stop retrieval service for the user, so that the reader can read the information and fast query. Universities can also use the most advanced information technology, communications and logistics facilities, build an open resource sharing and information exchange platform, it is convenient for the user to use the platform to search, access to all kinds of documents and materials, and through online chat rooms, virtual information room and virtual community and other ways to master the tacit knowledge.

Improved library service model

Based on a new type of information service model, the construction of resource sharing space requires university library to follow the "reader first" service standards, and implement the "people-oriented" service concept. Specifically, the university should be a reasonable allocation of staff, so that it can give full play to their ability in the post, thus showing the best working state. Colleges and universities should strengthen the education and training of staff, through learning to master the latest technology and skills, improve their professional level and computer level. Ability to develop special abilities for different positions. Only in this way can we understand the needs of users, and users with good communication, to provide users with more quality services. For reference, the university to carry out the network infrastructure and technical equipment, the use of maintenance training and other aspects of the training.

\section{Conclusion}

Construction of subject information sharing space, according to the user's disciplines, professional or subject to organize the space, to provide professional, personalized, diversified services, is an effective way to expand the subject service. Discipline service is a continuous and continuous process, the service effect of the embodiment of the need for a certain period of time. However, with the deepening of the subject service, and the prosperity of the information sharing space, it will have a profound impact on the scientific research development and scientific progress.

\section{Acknowledgement}

In this paper, the research was sponsored by Project of 2016 CALIS National Literature Information Center, named "A Study on Construction of Information Commons for Subject Service 
in University Library ”(2016026);Jilin Province Science of Education “12th five-year” planned project "Construction and Implementation of University library Resources and Service Support Platform for Key Subjects”(GH150212); Research project for higher education scientific launched by Jilin institute of Higher education in 2015, named“A Study on Construction of Information Commons based on Featured \& Leading Subjects " (JGJX2015D31);The "13th five-year" social science research project of the Education Department of Jilin Province, named“ A Study on Construction of Information Commons in University Library for Major Subject Construction ”(2016019).

\section{References}

[1] Huang Lidong. Library science research object and research scope [J]. Library Journal,2011,(5):2-5.

[2] Hu Jidong. On the establishment and perfection of subject librarian system [J]. library and information knowledge,2002,(6):78-79.

[3] Ke Ping. Development trend of World Library under the environment of digital and globalization [J]. University Library Work,2012,(2):18-24.

[4] Huang Lidong. Knowledge management in library entry point) reference service [J]. modern information,2008,(3):169-170.

[5] Huang Shaoru. The university library subject information sharing space construction of [J]. Library Journal,2011,(12):48-50. 